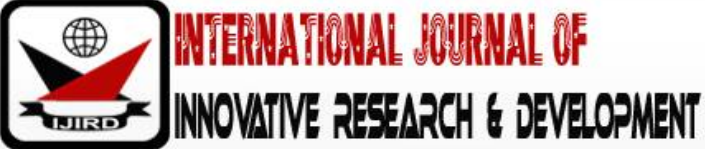

ISSN 2278-0211 (Online)

\section{Corporate Visioning and Organizational Transformation in Selected Deposit Money Banks in Enugu State, Nigeria}

\author{
Nwadike, Stanley Chukwuma \\ Postgraduate Student, Department of Management \\ University of Nigeria, Enugu Campus, Nigeria \\ Ekperi, Paul Madukwe \\ Doctoral Candidate, Institute for Development Studies, \\ University of Nigeria, Enugu Campus, Nigeria
}

\begin{abstract}
:
The broad objective of the study was to examine the effect of corporate visioning on organisational transformation in selected deposit money banks in Enugu State, Nigeria.The study adopted descriptive survey research design. Population of the study was 1043 staff of the selected deposit money banks; out of which a sample size of 281 staff were determined using Krejcie and Morgan statistical formulae.A total of 281 copies of the questionnaire were distributed, out of which 231 copies were correctly filled and returned; thus, 231 copies (respondents) were used for the study. Primary data were collected through structured questionnaire while secondary data were sourced from journals, books and internet. The primary instrument for data collection was designed on a 5-point Likert scale in line with the objectives of the study. The hypotheses were tested using simple linear regression analyses at 5\% probability level of significance. Findings revealed that: Shared vision significantly affects organisational competitive advantage of deposit money banks positively; Visionary leadership has a significant positive effect on operations of deposit money banks and Vision statement significantly improves organisational commitment to long term survival in the Deposit money banks. The study concluded that corporate visioning has a significant relationship and effect on organisational transformation. The study recommended that deposit money banks should adequately share their visions to their employees, have clear vision statement and install visionary leaders who consistently improve their operations and achieve competitive advantage in the market place.
\end{abstract}

Keywords: Corporate, visioning, transformation

\section{Introduction}

The competitive business environment has brought about a timely emphasis on the importance of a well formulated, communicated and implemented vision in guaranteeing the survival and growth of the business. As organisations battle each other in gaining large customer base, increase return on investment/profitability, move closer to her vision, remain relevant etc, the place of strong corporate visioning cannot be neglected. In a fast-changing world, the question for many senior managers is: "What leadership strategy is needed for my firm to stay competitive and to thrive?" To many consultants and academics, visionary leadership or leadership with vision as a core component is the answer. Although corporate trainers, scholars and management consultants often emphasize the importance of espousing a vision and even suggest characteristics of an effective vision, no one really knows what such a vision looks like (Avery, 2004 in Kantabutra and Avery, 2010).

Corporate vision cannot be said to be a modern business concept. It has been developed, used and discussed throughout centuries, from initial stage of the civilizations. However, a good number of those discussions were actually based on the relationship between vision and personal success rather than applications on the business (Suranga, 2014). The concept visioning became widely used in the planning process during the 1980s and 1990s; in its simplest form, it is the notion of creating images of the future to serve as goals or guides for planning decisions (Shipley, 2002).

Organisational transformation is a term referring collectively to such activities as reengineering, redesigning and redefining business systems (Samantaray, 2016). Organisational transformation is about organisational change which the changes goes to the depths of what an individual feels and will affect what people feel about the organisation, what they do in the organisation and may be what they hold dear to life (Ferlic, 2009). Visioning, when employed strategically to break free from the restrictions of the past, can be the source of transformational change (Finkenstein, Harvey, and Lawton, 2008). Harley-Davidson (HD) motorcycle, by pursuing a vision that excited its customers and employees, by putting vision at the heart of its strategy process thus creating the momentum needed to overcome the limitations of the past, was able to regenerate itself to win back market share and re-established itself as one of the United State of America's most dynamic corporations (Finkenstein et al., 2008). 
Studies have demonstrated how corporate visioning aided organisations in increasing performance and achieving organisational success. For instance, Vuuren (2010) reveals that Borbet SA (South Africa) an aluminium wheel manufacturer in South Africa experienced an improved productivity at the company has a result of the organisational members being aware of the vision statement of the organisation. He opined that the organisation succeeded in making company vision a part of their business strategy and that the successful implementation of a vision and values at Borbet SA have improved productivity, profitability, morale and quality of product at the company. Ekpunobi (2010) found out in her study that visionary leadership has impact on organisational transformation within the industry studied. The study further revealed that Corporate Vision was positively and significantly correlated with organisational transformation in the industry investigated.

Banking operations basically revolve around services. Therefore, customer-oriented performance is one of the key factors used in measuring the effectiveness of banking operations. Every service is designed to produce result. The result is underlined by efficiency, speed, honesty and cleanliness (Okonkwo, 2016). Due to poor visioning which is a strategic need in an organisation, banks have been affected. The Nigeria Deposit Insurance Corporation (NDIC) revealed that poor planning on the part of Nigeria Banks is not just a matter of quantitative techniques but more essentially that of attitude. Events of later revelations showed that not only did bankers not take strategic planning serious, even the contingency planning against systemic distress as well as their risk management framework which the Central Bank of Nigeria demanded as a sine qua non, were not rigorously applied until the advent of the crisis that swept away some of the executives. Organisations should highly be concerned about their vision when formulating strategies (Suranga, 2014). It was revealed that the implications of bank distress includes; customers losing of confidence in the banking industry, scaring away of investors and depositors, causes general depression in the banking industry etc (ArticlesNg, 2017). This affects the general banks profitability.

Bank owners/managers are supposed to be visionary leaders. NDIC revealed that some of the reasons why Alpha Merchant Bank PLC failed were due to weak corporate governance and management ineptitude. Kantabutra (2006) summarized in his work that realizing visions requires corporate leaders to develop strategies and plans, communicate their visions, align people and supporting systems, empower people to act on the vision, and motivate their followers. He also states that with appropriate vision and the realization approach, corporate leaders are expected to bring about sustainable performance. Although Nigeria banks have corporate visions, having a vision is not enough. The leaders (management) and staff of banking firms needs to deeply understand and align themselves to the vision, be guided by the vision and collectively work towards its realization continuously, this will enhance organisational transformation.

The purpose of the study was to investigate the effect of corporate visioning on organisational transformation of selected deposit money banks in Enugu State Nigeria.

\subsection{Statement of Problem}

It is believed that a clearly articulated and shared vision, fully implemented across an organisation, makes a profoundly positive difference. Also, some reviewed literatures state that vision creates road map for the organisation and guides transformational initiatives by setting a defined direction for the company's growth, and that vision is very essential to organisational growth and survival in modern competitive business environment. This goes ahead to give credence that vision is a necessity for any organisation which must be well written and communicated effectively to organisational members that will now lead to the development and implementation of strategies and policies that will bring about vision accomplishment.

As observed, every banking firm in Nigeria has a vision. The vision is placed conspicuously on the wall at banks various branches all over the nation. Even the banks that failed in the past and no longer in existence had a vision. The issue remains that it is not enough for an organisation to have a vision and place it on the wall for all to see. There is supposed to be a well-developed strategy to communicate and share this vision to all members of the organisation at different times so that their actions will be shaped by a consciousness of where the organisation wants to be in years to come but the availability of this strategy in banks is questionable. Some of the actions seen in banks today are capable of undermining their efforts towards realization of organisational vision. Nigeria banking industry is yet to fully live up to their potential in delivering the level of services that consumers are demanding especially with regards to technology. Some of the actions of bank staff do not adequately show they really know and have assimilated the organisational vision. Little wonder why some act the way they do to the detriment of their organisation. There have been cases of unethical behaviours such as fraud, greed and insider abuse amongst bank staff and management who are supposed to be guided by the company's vision of which ethics and professionalism is essential in its actualization. If leaders who are supposed to be visionary leaders are involved in cases mentioned above, they are passing a wrong message across to other organisational member(s) which is not helpful towards vision accomplishment. Some of the promotions and employment made in the banks are through favouritism and not merit which brings about poor performance. A good corporate visioning makes an organisation to hire, promote and develop the right personnel that can implement the vision thus leading to vision realization.

The above lacuna needs to be addressed. There is an urgent need to address these challenges because if not done, it will lead to or increase customers loss of confidence in the banking industry, scare away investors and depositors, bring about low profits due to low customer patronage and possibly bank insolvency or closure. Therefore, given these problems, the study sought to contribute to literature by creating a consciousness of the importance of corporate visioning and how a vision statement, shared vision together with visionary leadership can aid organisational transformation. 


\subsection{Objectives of the Study}

- Ascertain the extent to which shared vision affects organisational competitive advantage in the deposit money banks.

- Determine the extent to which visionary leadership affects the operation of deposit money banks.

- Determine the extent vision statement improves organisational commitment to long term survival in the deposit money banks.

\subsection{Research Questions}

- To what extent does shared vision affects organisational competitive advantage in the deposit money banks?

- To what extent does visionary leadership affect the operation of deposit money banks?

- To what extent does vision statement improve organisational commitment to long term survival in the deposit money banks?

\subsection{Research Hypotheses}

- $\quad$ Shared vision significantly affects organisational competitive advantage in the deposit money banks.

- Visionary leadership significantly affects the operation of deposit money banks.

- Vision statement significantly improves organisational commitment to long term survival in the deposit money banks.

\section{Review of Related Literature}

\subsection{Corporate Vision}

As stated earlier, corporate vision cannot be said to be a modern business concept. It has been developed, used and discussed throughout centuries, from initial stage of the civilizations. However, a good number of those discussions were actually based on the relationship between vision and personal success rather than applications on the business (Suranga, 2014). Vision was mostly a concept of researchers who studied political leadership and the leadership of social or religious movements before the 1980s (Kantabutra, 2008 in Ekpunobi, 2010). An organisational vision may be viewed as a picture of what the company would like to become in a given period (Idemobi, 2010).

\subsubsection{Corporate Visioning}

The concept visioning actually varies from the concept vision because it refers to an activity instead of a thing. A vision is considered as end product of the visioning process (Suranga, 2014). The concept visioning became widely used in the planning process during the 1980s and 1990s; in its simplest form, it is the notion of creating images of the future to serve as goals or guides for planning decisions (Shipley, 2002). The concept corporate visioning is a mental image of a possible and desirable future state of the organisation ... (which) articulates a view of a realistic, credible, attractive future for the organisation, a condition that is better in some important ways than what now exists (Bennis and Nanus, 1985 in Ekpunobi, 2010). Offering a slightly different insight into the definition of visioning, Finkelstein et al. (2008) posit that a vision is an output from a deliberate strategy process while visioning is the conversational technique used to develop a vision.

\subsubsection{Vision Statement}

Pearce and Robinson (2003) contend that a vision statement presents the firm's strategic intent that focuses the energies and resources of the company on achieving a desirable future. A vision is a statement that states where the organization intends to go and what to do to get to that intention (Rossouw et al. (2003) in Sandada 2014). Kenny (2014) puts it this way that a vision statement says what a firm wishes to be like in some years' to come. It's usually drawn up by senior management of an organisation, in an effort to take the thinking beyond day-to-day activity in a clear, memorable way.

\subsubsection{Visionary Leadership}

Leading according to Davies (2000) in Idemobi (2010) involves directing, influencing, and motivating employees to perform essential tasks. Visionary leadership is the ability to create and articulate clear visions providing purpose and meaning to the work of an organisation (Nanus, 1992; Sashkin, 1992 in Taylor et al., 2014). Visionary leadership is considered as a type of transformational leadership, it has the ability to quickly achieve the task to meet the organizational standards (Breevaart et al., 2014 in Cheema, Akram, and Javed, 2015).

\subsubsection{Shared Vision}

Shared visions directly create a positive impact on overall organizational performance through staff and customer satisfaction (Suranga, 2014). The better workers in an organization understand and align with their organizational vision statement, the higher the chances of their staying on board and being happier to contribute (Lavoie, 2017). Antonakis \& Hooijberg (2007); Nanus (1992) in O'Connell et al. (2011) posit that unless vision is well communicated, it is unlikely to have much impact on individuals or organisations. This also aligns with the view of O'connell et al. (2011) that continuing communication and elaboration of a vision brings it to life for members of an organisation. 


\subsubsection{Organisational Transformation}

Ferlic (2009) opines that organisational transformation is about organisational change which the changes goes to the depths of what an individual feels and will affect what people feel about the organisation, what they do in the organisation and may be what they hold dear to life. Samantaray (2016) defines organisational transformation as a term referring collectively to such activities as reengineering, redesigning and redefining business systems. The dominant enabling technology in transforming organisation is information and technology.

Cummins and Worley (2005) in Armstrong (2012) define organisational transformation as a process of radically altering the organisation's strategic direction, including fundamental changes in structures, processes and behaviours.

\subsection{Theoretical Framework}

\subsubsection{The Vision by Design Model}

This model was developed by Finkelstein et al. (2008). They state that a vision is an output from a deliberate strategy process while visioning is the conversational technique used to create a vision. In their work, they have three objectives; first, to illustrate that vision is a practical management tool that is fundamental to strategy making. Second, to demonstrate how visioning, when employed reflexively, works to better the quality of strategic decisions. Third, to argue that it is important for strategic leaders to develop a $360^{\circ}$ vision which is both grounded in the present and directed at the future. They posit that the power of visioning comes from its enabling organisations to break free from existing business constraints by channelling energies, time and resources into transformational activities and initiatives. To demonstrate the essentials of what is involved, they presented a four- dimensional visioning model that facilitates exploration of both the external and internal contexts of the business. The merit of the approach lies in breaking down vision into its component parts, lending simplicity and structure to the visioning process.

Finkelstein et al. (2008) model in effect liberates the organisation and its participants from the conventionalities of here-and-now (static) thinking in favor of a more dynamic past-present-future change orientation. Reflexivity is heightened and fresh ideas formed. Attention focuses on external and internal business drivers and on changes that could make a big difference to performance. Previously hidden possibilities for growth and improvement are revealed. In this way, the structure imposed by the visioning process paradoxically serves to improve levels of innovation within the leadership team. From being an imprecise idea that is difficult to actualize, visioning is thus used as a practical strategy tool to specify a set of static to dynamic state transitions. This study adopts this Model due to its greater relevance to the discourse.

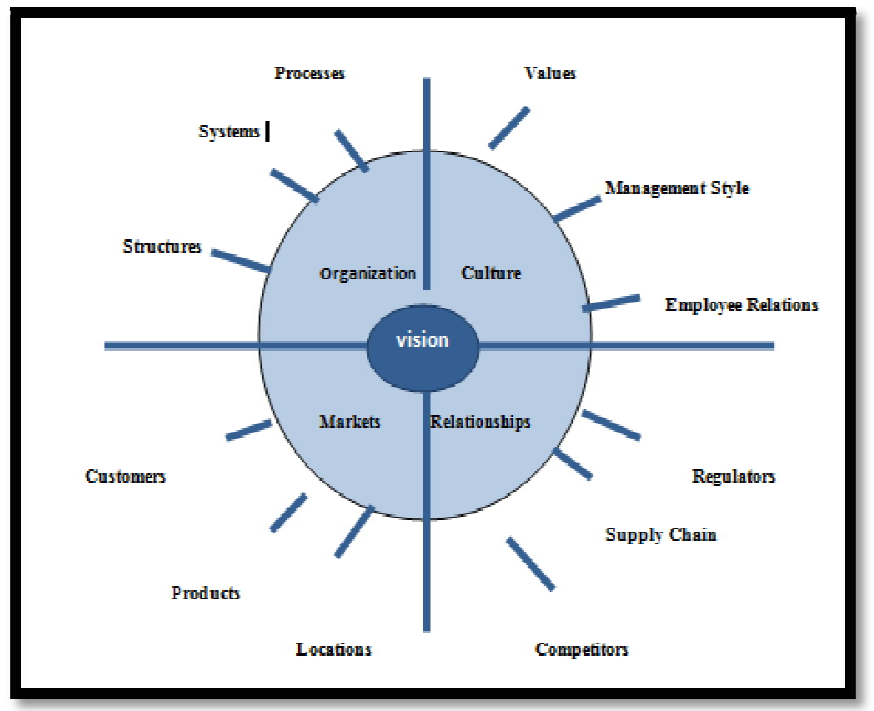

Figure 1: The Vision by Design Model

Source: Finkelstein Et Al. (2008)

\subsection{Methodology}

The study adopted a descriptive survey research method. Data were obtained from primary and secondary sources. The population of the study was 1043 comprising the senior staff and junior staff of Zenith Bank Plc, First Bank of Nigeria Plc, Fidelity Bank Plc and Guarantee Trust Bank Plc in Enugu State, Nigeria. A sample size of 281 was determined using the method (formula) employed by Krejcie and Morgan (1970). The instrument that was used for data collection in the study was structured questionnaire. The research made use of 5-point Likert scale system to get responses of respondents, they are; strongly agree, agree, undecided, disagree and strongly disagree. Data obtained were presented in tables and Percentages. The study adopted simple linear regression analyses to test all the hypotheses; these were done with the aid of Microsoft's.

Statistical Package for Social Sciences (SPSS version 18.0). The benchmark for rejection/acceptance of null hypothesis was $5 \%$ level of significance. Reject the null hypothesis if the P-value is greater than 0.05 otherwise do not reject. 


\section{Data Presentation and Analyses}

\subsection{Outcome of the Survey}

Two hundred and eighty-one (281) copies of questionnaire were administered to the senior and junior staff of the four selected banks in Enugu State. Of this number, two hundred and thirty-one (231) copies were correctly filled and returned; which represented Eighty-Two percent (82\%) response rate.

\subsubsection{Research Question 1}

Extent to which shared vision affects organisational competitive advantage in the deposit money banks in Enugu State

\begin{tabular}{|c|c|c|c|c|c|c|c|}
\hline Statements & $\begin{array}{c}\text { SA } \\
\text { (\%) }\end{array}$ & A (\%) & $\begin{array}{c}\text { UD } \\
\text { (\%) }\end{array}$ & D (\%) & $\begin{array}{c}\text { SD } \\
\text { (\%) }\end{array}$ & Mean & $\begin{array}{c}\text { Std. } \\
\text { Dev. }\end{array}$ \\
\hline $\begin{array}{c}\text { Sharing corporate vision to } \\
\text { employees inspires them to perform } \\
\text { better towards achieving the vision }\end{array}$ & 137 & $\begin{array}{c}85 \\
(59)\end{array}$ & $\begin{array}{c}3 \\
(37)\end{array}$ & $\begin{array}{c}4 \\
(2)\end{array}$ & $\begin{array}{c}2 \\
(1)\end{array}$ & 4.52 & 0.48 \\
\hline $\begin{array}{c}\text { Clarity of vision can bring about } \\
\text { innovation in the organisation }\end{array}$ & $\begin{array}{c}127 \\
(55)\end{array}$ & $\begin{array}{c}92 \\
(40)\end{array}$ & $\begin{array}{c}6 \\
(3)\end{array}$ & $\begin{array}{c}4 \\
(2)\end{array}$ & $\begin{array}{c}2 \\
(1)\end{array}$ & 4.46 & 0.51 \\
\hline $\begin{array}{c}\text { Periodic review of the organisationa } \\
\text { l vision gives the organisation an } \\
\text { edge over other firms that doesn't }\end{array}$ & $\begin{array}{c}121 \\
(52)\end{array}$ & $\begin{array}{c}90 \\
(39)\end{array}$ & $\begin{array}{c}12 \\
(5)\end{array}$ & $\begin{array}{c}6 \\
(3)\end{array}$ & $\begin{array}{c}2 \\
(1)\end{array}$ & 4.39 & 0.60 \\
\hline $\begin{array}{c}\text { A clearly understood vision allows } \\
\text { an organisation to develop } \\
\text { competitive advantage }\end{array}$ & $\begin{array}{c}131 \\
(57)\end{array}$ & $\begin{array}{c}85 \\
(38)\end{array}$ & $\begin{array}{c}3 \\
(1)\end{array}$ & $\begin{array}{c}7 \\
(3)\end{array}$ & $\begin{array}{c}5 \\
(2)\end{array}$ & 4.43 & 0.71 \\
\hline
\end{tabular}

Table 1: Extent to Which Shared Vision Affects Organisational Competitive Advantage

Source: Field Survey, 2018

Table 1 reveals that $137(59 \%)$ strongly agreed that sharing corporate vision to employees inspires them to perform better towards achieving the vision, 85(37\%) agreed to the statement, 3(1\%) were undecided, $4(2 \%)$ disagreed while $2(1 \%)$ strongly disagreed to the statement. With a mean response score of $4.52 \pm 0.48$, the respondents are of the opinion that sharing corporate vision to employees inspires them to perform better towards achieving the vision.

$127(55 \%)$ strongly agreed that clarity of vision can bring about innovation in the organisation, 92(40\%) agreed to the statement, $6(3 \%)$ were undecided, $4(2 \%)$ disagreed while $2(1 \%)$ strongly disagreed to the statement. With a mean response score of $4.46 \pm 0.51$, the respondents are of the opinion that clarity of vision can bring about innovation in the organisation.

$121(52 \%)$ strongly agreed that periodic review of the organisational vision gives the organisation an edge over other firms that doesn't, 90(39\%) agreed to the statement, 12(5\%) were undecided, 6(3\%) disagreed while 2(1\%) strongly disagreed to the statement. With a mean response score of $4.39 \pm 0.60$, the respondents are of the opinion that periodic review of the organisational vision gives the organisation an edge over other firms that doesn't.

$131(57 \%)$ strongly agreed a clearly understood vision allows an organisation to develop competitive advantage, $85(38 \%)$ agreed to the statement, 3(1\%) were undecided, $7(3 \%)$ disagreed while $5(2 \%)$ strongly disagreed to the statement. With a mean response score of $4.43 \pm 0.71$, the respondents are of the opinion that a clearly understood vision allows an organisation to develop competitive advantage.

\subsubsection{Research Question 2}

Extent to which visionary leadership affects the operation of deposit money banks

\begin{tabular}{|c|c|c|c|c|c|c|c|}
\hline Statements & $\begin{array}{c}\text { SA } \\
\mathbf{( \% )}\end{array}$ & $\begin{array}{c}\text { A } \\
(\mathbf{\% )}\end{array}$ & $\begin{array}{c}\text { UD } \\
\mathbf{( \% )}\end{array}$ & $\begin{array}{c}\text { D } \\
\mathbf{( \% )}\end{array}$ & $\begin{array}{c}\text { SD } \\
\mathbf{( \% )}\end{array}$ & Mean & $\begin{array}{c}\text { Std. } \\
\text { Dev. }\end{array}$ \\
\hline $\begin{array}{c}\text { Organisation is better managed by first } \\
\text { establishing a vision for it }\end{array}$ & $\begin{array}{c}142 \\
(61)\end{array}$ & $\begin{array}{c}77 \\
(33)\end{array}$ & $\begin{array}{c}5 \\
(2)\end{array}$ & $\begin{array}{c}3 \\
(1)\end{array}$ & $\begin{array}{c}4 \\
(2)\end{array}$ & 4.52 & 0.76 \\
\hline $\begin{array}{c}\text { Everything rise and fall on leadership. By } \\
\text { leaders guiding employees aright, successful } \\
\text { running of the organisation will be achieved }\end{array}$ & $\begin{array}{c}94 \\
(41)\end{array}$ & $\begin{array}{c}114 \\
(49)\end{array}$ & $\begin{array}{c}18 \\
(8)\end{array}$ & $\begin{array}{c}5 \\
(2)\end{array}$ & $\begin{array}{c}0 \\
(0)\end{array}$ & 4.29 & 0.70 \\
\hline $\begin{array}{c}\text { By adopting creative ideas, organisational } \\
\text { leaders improve their performance }\end{array}$ & $\begin{array}{c}115 \\
(50)\end{array}$ & $\begin{array}{c}95 \\
(41)\end{array}$ & $\begin{array}{c}14 \\
(6)\end{array}$ & $\begin{array}{c}6 \\
(3)\end{array}$ & $\begin{array}{c}1 \\
(0)\end{array}$ & 4.37 & 0.75 \\
\hline $\begin{array}{c}\text { Leaders must be able to communicate their } \\
\text { organisational vision to widen support of the } \\
\text { vision }\end{array}$ & $\begin{array}{c}115 \\
(50)\end{array}$ & $\begin{array}{c}103 \\
(45)\end{array}$ & $\begin{array}{c}8 \\
(3)\end{array}$ & $\begin{array}{c}4 \\
(2)\end{array}$ & $\begin{array}{c}1 \\
(0)\end{array}$ & 4.42 & 0.68 \\
\hline
\end{tabular}

Table 2: Extent to Which Visionary Leadership Affects the Operation of Deposit Money Banks Source: Field Survey, 2018

Table 2 shows that $142(61 \%)$ strongly agreed that Organisation is better managed by first establishing a vision for it, $77(33 \%)$ agreed to the statement, $5(2 \%)$ were undecided, $3(1 \%)$ disagreed while $4(2 \%)$ strongly disagreed to the 
statement. With a mean response score of $4.52 \pm 0.76$, the respondents are of the opinion that Organisation is better managed by first establishing a vision for it.

94(41\%) strongly agreed that everything rise and fall on leadership; by leaders guiding employees aright, successful running of the organisation will be achieved, 114(49\%) agreed to the statement, 18(9\%) were undecided, $5(2 \%)$ disagreed while none strongly disagreed to the statement. With a mean response score of $4.29 \pm 0.70$, the respondents are of the opinion that everything rise and fall on leadership; by leaders guiding employees aright, successful running of the organisation will be achieved.

$115(50 \%)$ strongly agreed that by adopting creative ideas, organisational leaders improve their performance, $95(41 \%)$ agreed to the statement, $14(6 \%)$ were undecided, $6(3 \%)$ disagreed while $1(0 \%)$ strongly disagreed to the statement. With a mean response score of $4.37 \pm 0.75$, the respondents are of the opinion that by adopting creative ideas, organisational leaders improve their performance.

$115(50 \%)$ strongly agreed that Leaders must be able to communicate their organisational vision to widen support of the vision, $103(45 \%)$ agreed to the statement, $8(3 \%)$ were undecided, $4(2 \%)$ disagreed while $1(0 \%)$ strongly disagreed to the statement. With a mean response score of $4.42 \pm 0.68$, the respondents are of the opinion that Leaders must be able to communicate their organisational vision to widen support of the vision.

\subsubsection{Research Question 3}

The Extent to which vision statement improves organisational commitment to long term survival in the Deposit money banks

\begin{tabular}{|c|c|c|c|c|c|c|c|}
\hline Statements & $\begin{array}{c}\text { SA } \\
(\%)\end{array}$ & $\begin{array}{c}A \\
(\%)\end{array}$ & $\begin{array}{c}\text { UD } \\
(\%)\end{array}$ & $\begin{array}{c}D \\
(\%)\end{array}$ & $\begin{array}{c}\text { SD } \\
(\%)\end{array}$ & Mean & $\begin{array}{l}\text { Std. } \\
\text { Dev. }\end{array}$ \\
\hline $\begin{array}{c}\text { Vision gives a sense of purpose as well as } \\
\text { provides great strength in times of } \\
\text { uncertainty }\end{array}$ & $\begin{array}{l}126 \\
(55)\end{array}$ & $\begin{array}{c}89 \\
(39)\end{array}$ & $\begin{array}{l}13 \\
(6)\end{array}$ & $\begin{array}{c}2 \\
(1)\end{array}$ & $\begin{array}{c}1 \\
(0)\end{array}$ & 4.46 & 0.68 \\
\hline $\begin{array}{l}\text { Vision statement is essential for giving } \\
\text { employees a higher purpose for work }\end{array}$ & $\begin{array}{c}96 \\
(42)\end{array}$ & $\begin{array}{l}100 \\
(43)\end{array}$ & $\begin{array}{c}28 \\
(23)\end{array}$ & $\begin{array}{c}4 \\
(2)\end{array}$ & $\begin{array}{c}3 \\
(1)\end{array}$ & 4.22 & 0.68 \\
\hline $\begin{array}{l}\text { Being vision driven will help an } \\
\text { organisation to have more focus about } \\
\text { their long-term future }\end{array}$ & $\begin{array}{l}121 \\
(52)\end{array}$ & $\begin{array}{c}98 \\
(42)\end{array}$ & $\begin{array}{l}10 \\
(4)\end{array}$ & $\begin{array}{c}2 \\
(1)\end{array}$ & - & 4.46 & 0.62 \\
\hline $\begin{array}{l}\text { Vision statement will shape your } \\
\text { organisation's policies and strategies } \\
\text { towards ensuring organisational survival }\end{array}$ & $\begin{array}{c}118 \\
(51)\end{array}$ & $\begin{array}{c}98 \\
(42)\end{array}$ & $\begin{array}{c}8 \\
(3)\end{array}$ & $\begin{array}{c}4 \\
(2)\end{array}$ & $\begin{array}{c}3 \\
(1)\end{array}$ & 4.40 & 0.75 \\
\hline
\end{tabular}

Table 3: Extent to Which Vision Statement Improves Organisational Commitment to

Long Term Survival in the Deposit Money Banks

Source: Field Survey, 2018

Table 3 shows that $126(55 \%)$ strongly agreed that vision gives a sense of purpose as well as provides great strength in times of uncertainty, $89(39 \%)$ agreed to the statement, $13(6 \%)$ were undecided, $2(1 \%)$ disagreed while $1(0 \%)$ strongly disagreed to the statement. With a mean response score of $4.46 \pm 0.68$, the respondents are of the opinion that vision gives a sense of purpose as well as provides great strength in times of uncertainty.

$96(42 \%)$ strongly agreed that vision statement is essential for giving employees a higher purpose for work, $100(43 \%)$ agreed to the statement, $28(23 \%)$ were undecided, $4(2 \%)$ disagreed while $3(1 \%)$ strongly disagreed to the statement. With a mean response score of $4.22 \pm 0.68$, the respondents are of the opinion that vision statement is essential for giving employees a higher purpose for work.

$121(52 \%)$ strongly agreed that being vision driven will help an organisation to have more focus about their longterm future, $98(42 \%)$ agreed to the statement, $10(4 \%)$ were undecided, $2(1 \%)$ disagreed while none strongly disagreed to the statement. With a mean response score of $4.46 \pm 0.62$, the respondents are of the opinion that being vision driven will help an organisation to have more focus about their long-term future.

$118(51 \%)$ strongly agreed that vision statement will shape your organisation's policies and strategies towards ensuring organisational survival, 98(42\%) agreed to the statement, 8(3\%) were undecided, 4(2\%) disagreed while 3(1\%) strongly disagreed to the statement. With a mean response score of $4.40 \pm 0.75$, the respondents are of the opinion that vision statement will shape your organisation's policies and strategies towards ensuring organisational survival.

\subsection{Test of Hypotheses}

\subsubsection{Hypothesis One}

- $\mathrm{H}_{0}$ : Shared vision does not significantly affect organisational competitive advantage in the Deposit money banks.

- $\mathrm{H}_{1}$ : Shared vision significantly affects organisational competitive advantage in the Deposit money banks. 


\begin{tabular}{|c|c|c|c|c|}
\hline Model & R & R Square & Adjusted R Square & Std. Error of the Estimate \\
\hline 1 & .672 & .451 & .448 & .71265 \\
\hline
\end{tabular}

Table 4: Model Summary

a. Predictors: (Constant), Shared Vision

b. Dependent Variable: Organisational Competitive Advantage

Source: SPSS Version 18.00

\begin{tabular}{|c|c|c|c|c|c|c|}
\hline \multirow{2}{*}{\multicolumn{2}{|c|}{ Model }} & \multicolumn{2}{c|}{$\begin{array}{c}\text { Unstandardized } \\
\text { Coefficients }\end{array}$} & $\begin{array}{c}\text { Standardized } \\
\text { Coefficients }\end{array}$ & \multirow{2}{*}{ T } & \multirow{2}{*}{ Sig. } \\
\cline { 3 - 6 } \multicolumn{2}{c|}{} & B & Std. Error & Beta & & \\
\hline \multirow{2}{*}{1} & (Constant) & 4.276 & .112 & & 3.769 & .000 \\
\cline { 2 - 7 } & Shared vision & .716 & .019 & .524 & 2.538 & .000 \\
\hline
\end{tabular}

Table 5: Coefficients ${ }^{a}$

Source: Spss Version 18.00

Dependent Variable: Organisational Competitive Advantage

$\begin{array}{lll}\beta & = & 0.524 \\ \mathrm{R}^{2} & = & 0.456 \\ \mathrm{~T} & = & 2.538\end{array}$

\subsubsection{Interpretation}

The correlation coefficient (R) which has a value of 0.672 indicates that there is positive relationship between Shared vision and organisational competitive advantage. The coefficient of determination ( $\mathrm{R}^{2}$ ) shows that $45.1 \%$ of the variation in organisational competitive advantage is explained by the model. The error of estimate is low, with a value of about .71265

The Shared vision coefficient of 0.524 indicates a positive effect of Shared vision on organisational competitive advantage, which is statistically significant (with $t=2.538$ ). We therefore reject the null hypothesis of no significant effect and conclude that Shared vision significantly affects organisational competitive advantage of deposit money banks in Enugu State at 5\% level of significance.

\subsubsection{Hypothesis Two}

- $\mathrm{H}_{0}$ : Visionary leadership does not significantly affect the operation of Deposit money banks

- $\mathrm{H}_{1}$ : Visionary leadership significantly affects the operation of Deposit money banks

\begin{tabular}{|c|c|c|c|c|}
\hline Model & R & R Square & Adjusted R Square & Std. Error of the Estimate \\
\hline 1 & .775 & .600 & .598 & .71484 \\
\hline
\end{tabular}

Table 6: Model Summary ${ }^{b}$

a. Predictors: (Constant), Visionary leadership

b. Dependent Variable: Operation

Source: SPSS Version 18.00

\begin{tabular}{|c|c|c|c|c|c|c|}
\hline \multicolumn{2}{|c|}{ Model } & Sum of Squares & Df & Mean Square & F & Sig. \\
\hline \multirow{3}{*}{1} & Regression & 265.871 & 1 & 265.871 & 520.295 & $.000^{\mathrm{a}}$ \\
\cline { 2 - 7 } & Residual & 116.969 & 229 & .511 & & \\
\cline { 2 - 7 } & Total & 382.840 & 230 & & & \\
\hline
\end{tabular}

Table 7: ANOVA $^{b}$

a. Predictors: (Constant), Visionary leadership

b. Dependent Variable: Operation

Source: SPSS Version 18.00

\begin{tabular}{|c|c|c|c|c|c|c|}
\hline \multirow{2}{*}{\multicolumn{2}{|c|}{ Model }} & \multicolumn{2}{|c|}{$\begin{array}{l}\text { Unstandardized } \\
\text { Coefficients }\end{array}$} & $\begin{array}{c}\text { Standardized } \\
\text { Coefficients }\end{array}$ & \multirow[t]{2}{*}{$\mathbf{T}$} & \multirow[t]{2}{*}{ Sig. } \\
\hline & & B & Std. Error & Beta & & \\
\hline \multirow[t]{2}{*}{1} & (Constant) & .243 & .056 & & 4.308 & .000 \\
\hline & Visionary leadership & .721 & .024 & .633 & 5.078 & .000 \\
\hline
\end{tabular}

Table 8: Coefficients ${ }^{a}$

Source: SPSS Version 18.00

a. Dependent Variable: Operation

$\begin{array}{cll}\beta & = & 0.633 \\ \mathrm{R}^{2} & = & 0.600 \\ \mathrm{~F} & = & 204.659 \\ \mathrm{~T} & = & 5.078\end{array}$




\subsubsection{Interpretation}

The regression sum of squares (265.871) is greater than the residual sum of squares (116.969), which indicates that more of the variation in the dependent variable is explained by the model. The significance value of the F statistics $(0.000)$ is less than 0.05 , which means that the variation explained by the model is not due to chance.

The correlation coefficient $(\mathrm{R})$ which has a value of 0.775 indicates that there is positive relationship between Visionary leadership and operation of Deposit money banks. The coefficient of determination $\left(\mathrm{R}^{2}\right)$ shows that $60.0 \%$ of the variation in the dependent variable is explained by the model.

The Visionary leadership coefficient of 0.633 indicates a positive significant effect between Visionary leadership and operation of Deposit money banks, which is statistically significant (with $t=5.078$ ). Therefore, we reject the null hypothesis of no significant effect and conclude that Visionary leadership significantly affects operation of Deposit money banks at $5 \%$ level of significance.

\subsubsection{Hypothesis Three}

- $\mathrm{H}_{0}$ : Vision statement does not significantly improve organisational commitment to long term survival in the Deposit money banks

- $\mathrm{H}_{1}$ : Vision statement significantly improves organisational commitment to long term survival in the Deposit money banks

\begin{tabular}{|c|c|c|c|c|}
\hline Model & R & R Square & Adjusted R Square & Std. Error of the Estimate \\
\hline 1 & $.892^{\mathrm{a}}$ & .796 & .795 & .50596 \\
\hline \multicolumn{5}{|c|}{ Table 9: Model Summaryb } \\
\hline
\end{tabular}

a. Predictors: (Constant), Vision Statement

b. Dependent Variable: Organisational Commitment to Long Term Survival

Source: Spss Version 18.00

\begin{tabular}{|c|c|c|c|c|c|c|}
\hline \multicolumn{2}{|c|}{ Model } & $\begin{array}{c}\text { Sum of } \\
\text { Squares }\end{array}$ & Df & $\begin{array}{c}\text { Mean } \\
\text { Square }\end{array}$ & F & Sig. \\
\hline \multirow{2}{*}{1} & Regression & 228.789 & 1 & 228.789 & 893.707 & $.000^{\text {a }}$ \\
\cline { 2 - 7 } & Residual & 58.721 & 229 & .256 & & \\
\cline { 2 - 7 } & Total & 287.510 & 230 & & & \\
\hline \multicolumn{7}{|c|}{ Table 10: Anovab }
\end{tabular}

Source: SPSS Version 18.00.

a. Predictors: (Constant), Vision Statement

b. Dependent Variable: Organisational Commitment to Long Term Survival

\begin{tabular}{|c|c|c|c|c|c|c|}
\hline \multirow{2}{*}{\multicolumn{2}{|c|}{ Model }} & \multicolumn{2}{|c|}{$\begin{array}{c}\text { Unstandardized } \\
\text { Coefficients }\end{array}$} & $\begin{array}{c}\text { Standardized } \\
\text { Coefficients }\end{array}$ & \multirow[t]{2}{*}{$\mathbf{T}$} & \multirow[t]{2}{*}{ Sig. } \\
\hline & & B & Std. Error & Beta & & \\
\hline \multirow[t]{2}{*}{1} & (Constant) & .331 & .040 & & 8.275 & .000 \\
\hline & Vision statement & .748 & .019 & .735 & 9.379 & .000 \\
\hline
\end{tabular}

Table 11: Coefficients ${ }^{a}$

Source: Spss Version 18.00

a. Dependent Variable: Organisational Commitment to Long Term Survival

$\begin{array}{lll}\beta & = & 0.735 \\ \mathrm{R}^{2} & = & 0.796 \\ \mathrm{~F} & = & 209.562 \\ \mathrm{~T} & = & 9.379\end{array}$

\subsubsection{Interpretation}

The regression sum of squares (228.789) is greater than the residual sum of squares (58.721), which indicates that more of the variation in the dependent variable is explained by the model. The significance value of the $\mathrm{F}$ statistics $(0.000)$ is less than 0.05 , which means that the variation explained by the model is not due to chance.

The correlation coefficient (R) which has a value of 0.892 indicates that there is positive relationship between Vision statement and organisational commitment to long term survival. The coefficient of determination $\left(\mathrm{R}^{2}\right)$ shows that $79.6 \%$ of the variation in organisational commitment to long term survival is explained by the model.

The Vision statement coefficient of 0.735 indicates a positive significance between Vision statement and organisational commitment to long term survival, which is statistically significant (with $t=9.379$ ). Therefore, we reject the null hypothesis and conclude that Vision statement significantly improves organisational commitment to long term survival in the Deposit money banks at $5 \%$ level of significance.

\section{Discussion of Findings}

The first objective of this study was to ascertain the extent to which shared vision affects organisational competitive advantage in the Deposit money banks in Enugu State. Theresponses to questions in table 1 were analysed with a view of achieving this objective. The grand mean of 4.46 indicated that majority of the respondents held the view 
that shared vision affects organisational competitive advantage of deposit money banks in Enugu State. The respondents' view based on the grand mean of 4.46 supported the findings of Vuuren (2010) who reported similar views from respondents drawn from South African automobile firm in his study. It however differs from that of Cheema et al. (2015) who reported that majority of their respondents were undecided with a grand mean of 2.1. To confirm the veracity of the respondents' view in this study, a simple regression from table $5(\beta=0.524, p=0.000)$ showed that Shared vision significantly affects organisational competitive advantage of deposit money banks in Enugu State positively. This finding further aligns with that of Vuuren (2010), Reid and Brentani (2010), and Sandada (2014) who found that shared vision is crucial in enhancing employees' performance and innovativeness which in turn confer competitive advantage on an organisation. It also agrees with Wadhwa and Parimoo (2016) who conclude that a shared vision can energize people by connecting them to the purpose of the organisation and see how their efforts contribute to the larger picture, if it is properly developed and implemented, vision can affect the premises that helps an organisation achieve long run success. It however differs from Cheema et al. (2015) who reported an insignificant effect between the independent and the dependent variables. Chen (2010), based on the results of his study advised Taiwanese banks to create a shared vision that is suitable for future global competition in compliance with the study findings, this supports what was found (result) in this particular Objective.

The second objective of this study was to determine the extent to which visionary leadership affects the operation of deposit money banks. Theresponses to questions in table 2 were analysed with a view of achieving this objective. The grand mean of 4.40 indicated that majority of the respondents held the view that Visionary leadership significantly affects operation of Deposit money banks. The simple linear regression result from table $8(\beta=0.633, p=0.000)$ further confirmed that visionary leadership has a significant positive effect on operations of deposit money banks in Enugu State. This finding agrees with Zhou et al (2016) who found that visionary leadership is positively associated with employee creativity in Chinese organisations and the relationship is positively mediated by employee knowledge-sharing. The finding also corroborates that of Taylor, Cornelius and Colvin (2014) whose work showed that significant relationships were found between visionary leadership and perceived organisational effectiveness. They posit that Visionary leaders with high leadership skills facilitated the greatest perceived organisational effectiveness in their respective firms. The finding is also partially related to the work of Ekpunobi (2010) who found that visionary leadership significantly impacts on the organizational transformation.

The third objective of the study was to determine the extent vision statement improves organisational commitment to long term survival in the deposit money banks. Theresponses to questions in table 3 were analysed with a view of achieving this objective. The grand mean of 4.39 indicated that majority of the respondents were of the view that vision statement affects organisational commitment to long term survival in the deposit money banks. The simple linear regression result from table $11(\beta=0.735, p=0.000)$ further confirmed that Vision statement significantly improves organisational commitment to long term survival in the Deposit money banks. This finding corroborates that of Taiwo, Lawal and Agwu (2016) who found that vision and mission statements that were properly crafted and implemented could influence organisational employee in their day-to-day activities and assist/help in the attainment of organisational goals with the mission and vision as a guiding light. Vuuren (2010) conducted a study and based on the findings, it was observed that the participants were 99\% aware of the vision statement at Borbet SA which means that Borbet SA had succeeded in making company vision a part of their business strategy. The study among other things submitted that the successful implementation of a vision and values at Borbet SA have improved productivity, profitability, morale and quality of product at the company. The research work is valuable to the finding in this study.

\section{Summary of Findings}

- $\quad$ Shared vision significantly affected organisational competitive advantage of deposit money banks in Enugu State positively $(\beta=0.524 ; \mathrm{t}=2.538 ; \mathrm{p}<0.05)$

- Visionary leadership had a significant positive effect on operations of deposit money banks in Enugu State $(\beta=$ 0.633 ; $\mathrm{t}=5.078 ; \mathrm{p}<0.05$ ).

- Vision statement significantly improved organisational commitment to long term survival in the Deposit money banks $(\beta=0.735 ; \mathrm{t}=9.379 ; \mathrm{p}<0.05)$

\section{Conclusion}

The major purpose of this study was to examine the effect of corporate visioning on organisational transformation in selected deposit money banks in Enugu State, Nigeria. From the hypotheses tested consequently, the study found that: shared vision, visionary leadership and vision statement had significant positive effect on organisational transformation. On the bases of these findings, the study concluded that corporate visioning has a significant relationship and effect on organisational transformation.

\section{Recommendations}

- Organisations should ensure they have clarity of vision which is shared to every single member of the organisation as this will help inspire the employees to put in their best towards achieving the vision as well as give the organisation a competitive edge over other organisations that do not share their vision to all staff. Also, organizational leaders should look into their vision with members of the organization once in a while to ensure that everyone is working in the right direction.

- It has been shown empirically that everything rises and falls on leadership and that by leaders guiding employees aright, successful running of the organisation will be achieved. Therefore banks and indeed all other organisations 
should ensure they install only visionary leaders to run the affairs of the organisation. Also, organizational leaders should ensure the adoption of creative ideas so as to improve their performance.

- Banks should ensure they have clear cut vision statement as that will enable them be resilient in the face of uncertainty, shape their organisation's policies and strategies and help enhance their long run organisational survival.

\section{References}

i. Armstrong, M. (2012). Armstrong's Hand Book of Human Resource Management Practice. UK: Printed and bound by Ashford Colour Press.

ii. ArticlesNG, (2017). Challenges Facing the Nigeria Banking Industry. Retrieved from http://articlesng.com/challenges-facing-nigeria-banking-industry/

iii. Ayaydin, H. \& Karaaslan, I. (2014). The Effect of Research and Development Investment on Firms' Financial Performance: Evidence from Manufacturing Firms in Turkey. Retrieved from http://www.beykon.org/dergi/2014/FALL/H.Ayaydin.pdf

iv. Cheema, S., Akram, A. \& Javed, F. (2015). Employee Engagement and Visionary Leadership: Impact on Customer and Employee Satisfaction.

v. Chen, J. (2010). Shared Vision Invention: A case from the financial industry. African Journal of Business Management, 4(18), 3861-3871.

vi. Ekpunobi, G. N. (2010). Corporate Visioning as a Strategy for Organisational Transformation in the Nigerian Textile Industry. Thesis submitted to University of Nigeria, Nsukka.

vii. Ferlic, K. (2009). What is Organisational Change and Organisational Transformation. Retrieved from http://ryuc.info/transformingtheorganisation/what_is_org_ch_trans.htm

viii. Finkelstein, S., Harvey, C. \&Lawton, T. (2008). Vision by design: a reflexive approach to enterprise regeneration. Journal of Business Strategy, 29(2), 4-13.

https://doi.org/10.1108/02756660810858107

ix. Idemobi, E.I. (2010). Theory and Practice of Management. Enugu, Nigeria: Gostak Printing and Pub. Co. Ltd.

x. Kantabutra, S. (2006). Relating Vision-based Leadership to Sustainable Business Performance: A Thai Perspective. Kravis Leadership Institute Leadership Review, 6, 37-53.

xi. Kantabutra, S. \& Avery, G.C. (2010). The Power of Vision: statements that resonate. Journal of Business Strategy, 31(1), 37-45.

xii. Knud, J. (2008). Visioning an Essential Business Process. Ted Rogers School of Business Management Ryerson University.

xiii. Krejcie, R.V. \& Morgan, D.W. (1970). Determining Sample Size for Research Activities. Retrieved from https://home.kku.ac.th/sompong/guest_speaker/krejcieandmorgan_article.pdf\&sa=U\&ved=0 ahUKEwiljay71pfbAhUSzqQKHzugCVAQFggQMAA\&usg=AOvVaw26W9fk1xwpzuYVajXH2EBD

xiv. Lavoie, A. (2017). How to Engage Employees through your Company Vision Statement. Retrieved from https://www.entrepreneur.com/article/290803

xv. Nigeria Deposit Insurance Corporation (NDIC): Case Study of Bank Failures in Nigeria, Vol. (1)

xvi. O'Connell O., Hickerson, K. \& Pillutla, A. (2011). Organisational Visioning: An Integrative Review. Group and Organisation Management Journal, 36(1), 103-125.

xvii. Okonkwo, O.S. (2016). Understanding service operations. CENBANK News, 39(7), ISSN NO 0331-7269

xviii. Onodugo, V.A., Ugwuonah, G.E. \& Ebinne, E.S. (2010). Social Science Research: Principles, Methods and Applications. Enugu, Nigeria: Published by EL DEMAK (Publishers).

xix. Pearce, J.A. \& Robinson, R.B. (2003). Strategic Management: Formulation, Implementation and control, $8^{\text {th }}$ Ed. NewYork: Mc GrawHill.

xx. Reid, S.E. \& Brentani, U. (2010). Market Vision and Market Visioning Competence: Impact on Early Performance for Radically New, High-Tech Products. Journal of Product Innovation Management.

xxi. Samantaray, M.N. (2016). Organisational Transformation: A Strategy for Gaining Competitive Advantage. Retrieved from www.indianmba.com/faculty_column/fc274/fc274.html

xxii. Sandada, M. (2014). Mission and Vision, Environmental Scanning and Formality of Strategic Planning as Predictors of The Performance of Small and Medium Enterprises (Smes) In the Gauteng Province of South Africa. Ecoforum, Volume 3, Issue 2 (5).

xxiii. Shipley, R. (2002). Visioning in Planning: Is the Practice Based on Sound Theory?School of Planning, University of Waterloo, Ontario N2L 3G1, Canada. Retrieved from http://journals.sagepub.com/doi/abs/10.1068/a3461

xxiv. Suranga, J.M. (2014). Proceedings of the HR Conference, 01(01).

xxv. Taiwo, A.A., Lawal, F.A. \& Agwu, M.E. (2016). Vision and Mission in Organisation: Myth or Heuristic Device? The International Journal of Business \& Management (ISSN 2321-8916)

xxvi. Taylor, C.M., Cornelius, C.J., \&Colvin, K. (2014). Visionary Leadership and its Relationship to Organisational Effectiveness. Leadership \& Organisation Development Journal, 35(6), 566-583. https://doi.org/10.1108/LODJ-10-2012-0130 
xxvii. Vuuren, B.V. (2010). The Impact of Company Vision and Values on the Success of an Automotive Company in Nelson Mandela Bay (The Case of Borbet South Africa). Paper Submitted to Nelson Mandela Metropolitan University.

xxviii. Wadhwa, S. and Parimoo, D. (2016). Impact of Vision and Mission on Organisational Performance in Indian Context. The International Journal of Business and Management (ISSN 2321-8916).

xxix. Zhou, L., Zhao, S., Tian, F., Zhang, X. and Chen, S. (2016). Visionary Leadership and Employee Creativity in China. International Journal of Manpower, https://doi.org/10.1108/IJM-04-2016-0092 